\title{
PKM KELOMPOK PETAMBAK UDANG DALAM UPAYA MEMANTAU DAN MENJAGA KUALITAS TAMBAK DI KECAMATAN MLONGGO KABUPATEN JEPARA
}

\author{
Buang Budi Wahono', Dias Prihatmoko², Luky Mudiarti ${ }^{3}$ \\ ${ }^{1}$ Fakultas Teknik, Universitas Islam Nahdlatul Ulama Jepara \\ email: budihono78@gmail.com \\ ${ }^{2}$ Fakultas Teknik, Universitas Islam Nahdlatul Ulama Jepara \\ email: diasprihatmoko@gmail.com \\ ${ }^{3}$ Fakultas Budidaya Perairan, Universitas Islam Nahdlatul Ulama Jepara \\ email: mlukymudiarti@yahoo.co.id
}

\begin{abstract}
Gumuk Mas and Udang Lestari is a group of shrimp farmers in the Kec. Mlonggo Kab. Jepara. in checking water quality still uses traditional methods, namely by seeing the shrimp floating on the surface of the pond. if there is, the shrimp lacks oxygen, is prone to disease and will interfere with its breeding. when approaching the harvest time the shrimp farmers turn on the waterwheel continuously every day so that the shrimp does not lack DO (Dissolved Oxygen), even if the waterwheel continues then it will result in excess DO and wasteful electricity. Therefore we need a solution for checking water quality and waterwheel control. this activity proposes two main activities, namely training and farm management skills well related to monitoring and control of Dissolved Oxygen. this activity so that shrimp farmers can monitor the quality of shrimp pond water at any time. if water quality is lacking or exceeds the limit, prevention activities can be carried out as soon as possible and can increase crop yields and the welfare of shrimp farmers.
\end{abstract}

Keywords: Water Quality, Wind Control, Shrimp Pond, DO, Shrimp Farmers

\begin{abstract}
ABSTRAK
Kelompok Petambak Gumuk Mas dan Udang Lestari merupakan kelompok petambak udang di Kec. Mlonggo Kab. Jepara. Selama ini dalam mengecek kualitas air dengan cara tradisional yaitu dengan melihat adanya udang yang mengambang di permukaan tambak, padahal kejadian tersebut merupakan sesuatu hal yang sudah terlambat karena udang sudah kekurangan oksigen dan secara otomatis udang rawan terkena penyakit serta akan mengganggu perkembangbiakannya. Selanjutnya saat mendekati masa panen para petambak udang menyalakan kincir air terus menerus setiap hari agar udang tidak kekurangan DO (Oksigen Terlarut), padahal jika kincir dinyalakan terus menerus maka akan berakibat kondisi DO berlebihan dan pemborosan energi listrik. Maka dari itu perlu solusi untuk pengecekan kualitas air serta control kincir air. Pada kegiatan pengabdian ini diusulkan dua kegiatan utama, yaitu pelatihan dan keterampilan pengeloaan tambak udang secara baik terkait dengan monitoring dan kontrol Oksigen Terlarut. Beberapa kegiatan tersebut dimaksudkan agar para petambak udang dapat setiap saat memonitor kualitas air tambak udang. Jadi jika didapat kualitas air yang kurang atau bahkan melebihi batas, maka akan dapat
\end{abstract}


dilakukan berbagai upaya pencegahannya sesegera mungkinyang pada akhirnya akan dapat meningkatkan hasil panen serta kesejahteraan para petambak udang.

Kata Kunci: Kualitas Air, Kontrol Kincir, Tambak Udang, DO, Petambak Udang

\section{PENDAHULUAN}

Kelompok Petambak Gumuk Mas dan Kelompok Petambak Udang Lestari adalah dua diantara beberapa kelompok petambak udang di Kec. Mlonggo Kabupaten Jepara. Kelompok Petambak Gumuk Mas mempunyai anggota sebanyak 16 orang petambak yang di ketuai oleh bapak Dwi Harno sedangkan Kelompok Petambak Udang Lestari mempunyai anggota sebanyak 11 orang petambak yang diketuai oleh bapak Siswanto. Masing-masing petambak mempunyai lahan berupa petakan tambak dengan luas yang bervariasi. Luas lahan Kelompok Gumuk Mas 10,7 Ha dan Luas Iahan Kelompok Udang Lestari 1,8 Ha.

Gambar 1 dibawah adalah gambar area tambak Kelompok Petambak Gumuk Mas dan Udang Lestari yang ada di desa Karanggondang dan Sekuro. Kebanyakan kelompok tersebut membudidaya udang vaname, waktu budidaya udang vaname membutuhkan waktu kurang lebih $75 \mathrm{~s} / \mathrm{d} 90$ hari (Ike T dan A Nawang, 2012), jadi dalam satu tahun petambak bisa panen sebanyak 3 kali. Sedangkan untuk panen yang dihasilkan pun berbeda-beda setiap masa budidaya yaitu sekitar 1 ton s/d 3 ton per Ha. (Slamet, S, Dede S, Mohammad A, dan Sofiati, 2009)

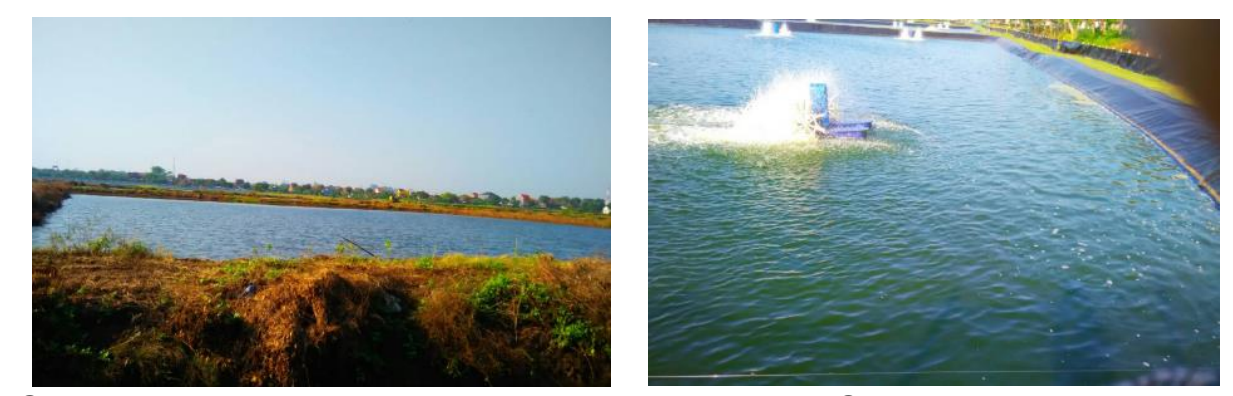

Gambar 1. Area Tambak kelompok petambak udang Gumuk Mas dan Udang Untuk meningkatkan kualitas dan kuantitas produksi secara maksimal

usaha budidaya udang memerlukan manajemen kualitas air yang bagus dalam petakan tambak untuk media tumbuh udang yang dipelihara. Manajemen kualitas air tersebut terkait dengan menjaga kestabilan semua kualitas air tambak udang. Kualitas air tersebut antara lain adalah derajat keasaman $(\mathrm{PH})$, dissolve oxygen (DO), Suhu, kadar garam (Salinitas), Kualitas air tersebut memegang peranan penting dalam pengelolaan tambak udang. Kegagalan menjaga air ini menjadikan udang yang dibudidayakan mudah mati dan terserang penyakit sehingga gagal panen. (Goib W, 2010).

Menurut data dari kantor deputi menegristek bidang pendayagunaan ilmu pengetahuan dan teknologi tentang TTG budidaya perikanan khususnya 
udang, agar pertumbuhan udang bisa maksimal maka di lokasi petakan tambak harus dijaga beberapa baik fisika maupun kimia, untuk beberapa fisik diantaranya suhu / temperatur sekitar 26 sampai dengan 30 derajat $\mathrm{C}$, kadar garam / salinitas sekitar 10 sampai dengan 30 permil, kecerahan air sekitar 25 sampai dengan $30 \mathrm{~cm}$ diukur dengan secchi disk, derajat keasaman $(\mathrm{pH})$ sekitar 7,5 sampai dengan 8,5 dan DO (Oksigen Terlarut) sekitar 4 sampai dengan $8 \mathrm{mg} /$ liter. Serta masih ada beberapa yang lainnya.

Untuk mengukur kualitas air tersebut harus di ukur menggunakan alat ukur baik analog maupun digital secara manual dan periodik, serta harganya masing-masing alat ukur yang tidak murah bagi para petambak udang. Hal ini tentunya akan sangat memberatkan bagi para petambak untuk bisa memenuhinya. Menjaga nilai kualitas air ini dilakukan mulai dari proses awal yaitu proses pengolahan air sebelum tebar benih udang, dalam proses tersebut kualitas air harus benar-benar dijaga. (Yovi M S, 2016).

Selama ini yang dilakukan kelompok petambak udang Gumuk Mas adalah dengan cara mengecek kualitas air tersebut secara tradisional yaitu dengan cara melihat apakah ada udang yang mengambang di permukaan tambak atau tidak, jika ada udang dipermukaan tambak maka hal itu pertanda bahwa salah satu kualitas air menurun yang berakibat udang kekurangan DO (Oksigen Terlarut), padahal sebenarnya kejadian tersebut merupakan sesuatu hal yang sudah terlambat dan secara otomatis udang mudah terkena penyakit serta akan mengganggu perkembangbiakan udang, (Katherin I, 2008). Sedangkan untuk kelompok petambak Udang Lestari sudah ada alat ukur kualitas air tetapi hanya untuk mengecek DO saja, untuk alat ukur yang lain belum mempunyai.

Demikian juga halnya jika derajat keasaman atau $\mathrm{pH}$ tidak pada batas normal maka akan mengakibatkan kulit udang mengelupas dan mudah terserang penyakit, sama halnya untuk - yang lain, seperti suhu, kadar garam, kecerahan air, dll. Maka dari itu untuk mendapatkan hasil yang baik, para petambak udang harus senantiasa dan secara periodik memantau nilai kualitas air tersebut. Konsekuensinya para petambak udang harus menyediakan beberapa alat ukur yang harganya tidak murah, Tentunya ini adalah hal yang memberatkan bagi para petambak udang. Oleh karena itu perlu adanya solusi teknologi yang efektif dan aplikatif untuk membantu petambak udang dalam memonitor kualitas air tersebut. Hal ini akan sangat membantu kelompok petambak udang dalam proses budidaya udang serta akan menjadi informasi awal untuk pencegahan penyakit pada proses budidaya udang. Yang pada akhirnya akan berdampak pada meningkatnya hasil panen budidaya udang serta meningkatnya kesejahteraan masyarakat petambak udang di kabupaten jepara.

Saat mendekati masa panen yang dilakukan para petambak udang adalah menyalakan kincir air terus menerus setiap hari agar supaya udang tidak kekurangan DO, padahal jika kincir dinyalakan terus menerus maka akan berakibat kondisi DO bisa berlebihan serta mengakibatkan pemborosan energi 
listrik. Jikalau DO berlebihan bisa berdampak kurang baik juga bagi pertumbuhan udang. Oleh karena itu perlu adanya solusi teknologi menggunakan sensor yang akan berjalan otomatis sesuai dengan nilai DO yang diukur serta nilai tersebut akan dijaga agar kondisinya selalu dalam keadaan yang normal.

\section{METODE PELAKSANAAN}

Adapun metode pelaksanaan kegiatan yang dilakukan oleh tim pengusul Iptek bagi Masyarakat kelompok petambak udang adalah dengan diadakannya beberapa kegiatan terkait dengan pelatihan, keterampilan, dan pendampingan kelompok tani beberapa diantaranya yaitu : (1). Pelatihan Proses pengolahan air tambak udang, Pengetahuan dan keterampilan proses budidaya udang yang efektif dan efisien, Pengetahuan dan keterampilan tentang manajemen kualitas air yang efektif dan efisien. Kegiatan pelatihan tersebut dilakukan dengan tujuan agar petambak udang memiliki pengetahuan memanajemen tambak udang agar mendapat hasil panen yang optimal. (2). Keterampilan pemakaian alat monitoring kualitas air dan Keterampilan pemasangan alat kontrol kincir menggunakan switch 3 phase. Kegiatan keterampilan ini dimaksudkan agar petambak udang mempunyai keterampilan dalam pemakaian peralatan monitoring kualitas air tambak udang, serta pengoperasian alat control kincir. Kedepannya diharapkan agar petambak mendapat bekal IPTEK serta dapat memperbaiki jika ada kerusakan dalam alat tersebut.

Dalam kegiatan tersebut, partisipasi mitra adalah sebagai peserta kegiatan pelatihan dan keterampilan manajemen atau pengelolaan tambak udang. Selanjutnya mitra dan tim pengusul bersama-sama membuat dan merancang alat kontrol kincir menggunakan switch 3 phase.

Produk yang akan dihasilkan selama pelaksanaan program pengabdian kepada masyarakat ini adalah berupa alat monitoring kualitas air dan alat kontrol kincir menggunakan switch 3 phase untuk mengoptimalkan nilai oksigen terlarut dalam air. Terkait dengan hal tersebut, berikut ini dijelaskan beberapa tentang metode yang dipakai dalam pelaksanaan program pengabdian tersebut.

Alat kontrol kincir dengan menggunakan switch 3 phase, dibuat dengan menggunakan switch 3 phase setiap kincir menggunakan satu switch dengan menggunakan input listrik 3 phase dari tenaga diesel. Switch 3 phase ini berupa kontaktor magnetic yang berfungsi untuk start dan stop motor 3 phase. Sistem pemasangannya adalah dengan menghubungkan koil K1 yaitu A1 dan A2 dengan sumber tegangan listrik 220 Volt melalui peralatan tombol Start dan Stop. Jika tombol Start menyala maka akan menghubungkan Koil K1 ke sumber tegangan yang mengakibatkan kontak pada kontaktor bekerja. Kemudian apabila awalnya pada kondisi NO (terbuka) maka setelah kontaktor bekerja akan merubah posisi dari awalnya NO menjadi NC (tertutup). 
Sedangkan untuk tombol Stop bertindak sebagai tombol untuk pemutus arus dan tegangan listrik. Sehingga sistem kerjanya kebalikan dari tombol Start. Yaitu jika tombol stopmenyala maka akan memutus arus dan tegangan sumber listrik tersebut pada koil K1. Sehingga peralatan yang dikontrol akan mati. Sistem ini dapat berjalan secara manual dan secara otomatis sesuai dengan keperluan.

\section{HASIL DAN PEMBAHASAN}

1. Kegiatan Training / Pelatihan

Kegiatan Training atau Pelatihan yang dilakukan terhadap Kelompok Petambak Gumuk Mas dan Kelompok Petambak Udang Lestari, selama kegiatan tim pengusul menyampaikan beberapa materi, diantaranya materi yang disampaikan pada pelatihan tersebut diantaranya yaitu :

a. Proses pengolahan air tambak udang.

b. Pengetahuan dan keterampilan proses budidaya udang yang efektif dan efisien

c. Pengetahuan dan keterampilan tentang manajemen kualitas air yang efektif dan efisien

Kegiatan kemitraan dengan kelompok Petambak Gumuk Mas dan Kelompok Petambak Udang Lestari ini dilaksanakan dengan cara mengajarkan tentang penerapan manajemen kontrol kualitas air tambak. Teknologi yang ditransfer kepada mitra adalah terkait dengan seperti apa mitra memantau kondisi kualitas air tambak, apakah kualitas tersebut dalam keadaan normal atau tidak, dan beberapa nilai kualitas air yang ditransfer ke mitra bersifat portable, sehingga mitra mudah memahaminya. Kemudian diadakan pelatihan dan praktik Manajemen Kontrol Kualitas Air tambak kepada masyarakat yang diikuti oleh kedua kelompok petambak.

Kegiatan Transfer teknologi ini dilakukan dengan harapan bisa bermanfaat bagi mitra dan bisa membantu mitra dalam mengelola tambak udangnya. Transfer teknologi dibuat sederhana dan mudah dipahami yang nantinya mudah diaplikasikan oleh mitra terkait dengan pengelolaan kualitas air tambak. Sehingga diharapkan dengan kegiatan transfer teknologi ini dapat mereduksi masyarakat petambak untuk bisa menjaga kualitas air tambaknya. Peningkatan kualitas air tambak yang optimal akan dapat meningkatkan produksi udang. Kemampuan untuk menjaga kualitas air ini sangat diperlukan untuk budidaya udang, hal ini dikarenakan kualitas air merupakan kunci dari kemampuan peningkatan produksi. Persyaratan kualitas air tersebut adalah tersedianya oksigen yang terlarut di dalam air tambak udang. Untuk keperluan menjaga kualitas oksigen terlarut pada tambak digunakan peralatan berupa kincir air.

Selain manajemen kualitas air tambak, juga diberikan pengetahuan dan ketrampilan tentang proses budidaya udang yang efektif dan efisien serta pemanfaatan limbah kotoran udang menjadi pupuk organik yang dapat 
digunakan untuk tanaman. Suasana saat pelatihan monitoring kualitas air dapat dilihat pada gambar dibawah ini:

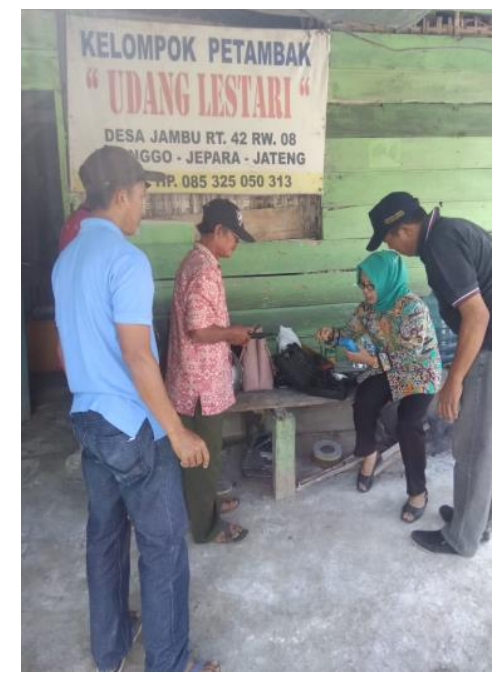

Gambar 2. Pelatihan Pelatihan Pengelolaan Kualitas Air Tambak

2. Kegiatan Keterampilan

Kegiatan yang kedua yaitu keterampilan kepada Kelompok Petambak Gumuk Mas dan Kelompok Petambak Udang Lestari,. Pada kegiatan ini dilakukan beberapa keterampilan diantaranya yaitu keterampilan pemasangan alat monitoring kualitas air dan keterampilan pemasangan alat kontrol kincir air otomatis menggunakan switch 3 phase.

Kegiatan ketrampilan kepada kelompok Petambak Gumuk Mas dan Kelompok Petambak Udang Lestari ini diantaranya tentang ketrampilan penggunaan dan pemasangan alat monitoring kualitas air tambak serta ketrampilan pemasangan alat kontrol kincir air otomatis menggunakan switch 3 phase. Kontrol kincir air ini dapat bekerja mulai dari proses setting waktu, proses setting kincir air ON dan proses setting kincir air OFF. Semua akan berjalan secara otomatis setelah setting waktu telah ditentukan. Kincir air dapat bekerja apabila driver relay mendapat logika 1 dari output mikrokontroller yang menjadi input untuk driver relay. Driver relay akan menghidupkan motor DC untuk memutarkan kincir air yang akan menyuplaikan kandungan oksigen pada tambak udang. Alat ini untuk mempermudah pekerjaan petambak dalam mengoperasikan kincir air pada saat malam hari dengan menggunakan timer sebagai sistem yang otomatis untuk mengontrol waktu hidup dan waktu mati kincir air serta menjaga tingkat kelarutan oksigen dalam tambak udang pada waktu malam hari saat fitoplonkton tidak bisa berfotosintesa yang efisien dan hemat energi serta dapat meningkatkan hasil produksi tambak udang.. Kegiatan keterampilan alat kontrol kincir tersebut dapat dilihat pada gambar dibawah ini 


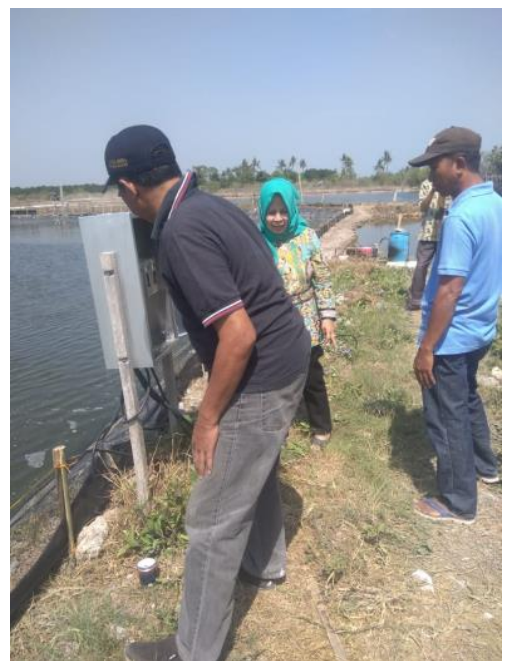

Gambar 3. Keterampilan Pemakaian Alat Monitoring dan Kontrol Kincir

\section{KESIMPULAN}

Berdasarkan pengabdian yang telah dilakukan dapat disimpulkan bahwa, Kedua mitra pengabdian yaitu Kelompok Petambak Gumuk Mas dan Kelompok Petambak Udang Lestari sangat antusias dalam kegiatan pelatihan dan keterampilan, karena manajemen kualitas air tersebut sangat diperlukan dalam pengelolaan tambak udang, karena dapat meningkatkan serta mengoptimalkan hasil panen yang pada akhirnya dapat meningkatkan kesejahteraan para petambak udang.

\section{UCAPAN TERIMA KASIH}

Terima kasih disampaikan kepada kementrian riset dan pendidikan tinggi (Kemenristekdikti) atas dukungan dana pengabdian kepada masyarakat di kecamatan mlonggo, serta dukungan dari LPPM Universitas Islam Nahdlatul Ulama Jepara dan kelompok petambak udang di Desa Sekuro dan Desa Karanggondang.

\section{DAFTAR RUJUKAN}

Yovi M S, (2016), Monitoring Kualitas Air Pada Budidaya Udang Berbasis ATMEGA328 Yang Terkonfigurasi Bluetooth HC-05. E-Journal Prodi Elektronika Edisi Proyek Akhir D3. Universitas Negeri Yogyakarta.

Goib W, (2010), Pembuatan Sistem Monitoring Kualitas Air dan Aplikasinya dalam Pengelolaan Tambak Udang. Teknologi Indonesia Vol 33 No 2: $107-113$

Ike T dan A Nawang, (2012), Pemantauan Kualitas Air pada Pemeliharaan Udang Vaname di Tambak Dengan Sistem Tradisional Plus. Prosiding Indoaqua - Forum Inovasi Teknologi Aquakultur. Hal 85 - 89. 
Katherin I, (2008), Pembuatan Modul Kontrol Kualitas Air Tambak Udang sebagai Sarana Pembelajaran Perbaikan Teknik Budidaya Udang, Jurusan Teknik Fisika FTI - ITS Surabaya.

Slamet, S, Dede S, Mohammad A, dan Sofiati, (2009), Budidaya Udang Vannamei Semi Intensif Dengan Metode Sirkulasi Tertutup Untuk Menghindari Serangan Virus. Jurnal IImiah Perikanan dan Kelautan Vol 1 No 2 November 2009. : 121 - 127.

TTG Budidaya Perairan, Budidaya Udang windu. Kantor Deputi Menegristek Bidang Pendayagunaan dan Pemasyarakatan IImu Pengetahuan dan Teknologi, Jakarta. 